\title{
TOWARD A \\ NUCLEAR PEACE
}




\section{Also by Michael J. Mazarr}

Missile Defenses and Asian-Pacific Security

Light Forces and the Future of U.S. Military Strategy

*START and the Future of Deterrence

*Also published by Macmillan 


\title{
TOWARD A NUCLEAR PEACE
}

The Future of Nuclear Weapons

\author{
Edited by \\ Michael J. Mazarr \\ and
}

Alexander T. Lennon

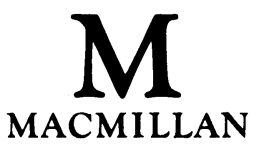


ISBN 978-1-349-60795-2

ISBN 978-1-349-60793-8 (eBook)

DOI 10.1007/978-1-349-60793-8

(C) Center for Strategic and International Studies 1994

Softcover reprint of the hardcover 1st edition 1994 978-0-312-10404-7

All rights reserved. No reproduction, copy or transmission of this publication may be made without written permission.

No paragraph of this publication may be reproduced, copied or transmitted save with written permission or in accordance with the provisions of the Copyright, Designs and Patents Act 1988, or under the terms of any licence permitting limited copying issued by the Copyright Licensing Agency, 90 Tottenham Court Road, London W1P 9HE.

Any person who does any unauthorised act in relation to this publication may be liable to criminal prosecution and civil claims for damages.

First published 1994 by THE MACMILLAN PRESS LTD

Houndmills, Basingstoke, Hampshire RG21 2XS

and London

Companies and representatives

throughout the world

A catalogue record for this book is available from the British Library.

Design by Acme Art, Inc., New York, NY 


\section{CONTENTS}

\section{Part I: United States Nuclear Policy}

by Nuclear Strategy Study Group

1. The Future of Arms Control $\ldots \ldots \ldots$

2. The Case for Further Progress $\ldots \ldots \ldots \ldots$

3. How Much Is Enough? $\ldots \ldots \ldots \ldots \ldots$

4. Deterrence in Europe . . . . . . . . . . . . . . . 35

5. Regional Deterrence $\ldots \ldots \ldots \ldots$. . . . . . . . 57

6. Strategic Defenses . . . . . . . . . . . . . . . . . . .69

7. Nuclear End States $\ldots \ldots$. . . . . . . . . . . . . . 87

Appendix 1

First-Strike Survivability and Defense Penetration

by Steve Fetter . . . . . . . . . . . . . . . . . . 103

Appendix 2

Military Targets for a Minimum Deterrent:

After the Cold War, How Much Is Enough?

by Michael J. Mazarr . . . . . . . . . . . . . . . . . . 113 


\section{Part II: European Nuclear Forces}

8. Britain, Nuclear Weapons, and the Future of Arms Control

by Lawrence Freedman . . . . . . . . . . . . . . . 145

9. French Nuclear Policy: Adapting the Gaullist Legacy to the Post-Cold War World

by Edward A. Kolodziej . . . . . . . . . . . . . . . . 165

10. Russian Views of Nuclear Weapons

by Sergei Rogov . . . . . . . . . . . . . . . . . . . 205

About the Authors . . . . . . . . . . . . . . . . 217

About the Editors . . . . . . . . . . . . . . . . 219

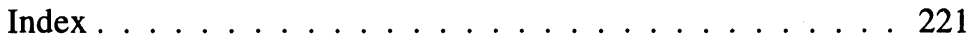

